\title{
Inheritance of Resistance to Blackeye Cowpea Mosaic Virus in White Acre- BVR' Cowpea
}

\author{
Sohedjie Ouattara' and Oyette L. Chambliss ${ }^{2}$ \\ Department of Horticulture and Alabama Agricultural Experiment \\ Station, Auburn University, Auburn, AL 36849
}

Additional index words. Vigna unguiculata, cowpea stunt, enzyme-linked
immunosorbent assay, ELISA, gamma immunoglobulin, symptomatology

Abstract. Reciprocal crosses were made between 'White Acre-BVR', resistant to blackeye cowpea mosaic virus (BICMV), and the susceptible 'California Blackeye No. 5' cowpea [Vigna unguiculata (L.) Walp.]. Seedlings from 'California Blackeye No. 5', 'White Acre-BVR', $F_{1}, F_{2}$, and backcrosses were mechanically inoculated with BICMV, and evaluated 4 weeks later for symptom expression in the greenhouse. Plants were assayed by enzyme-linked immunosorbent assay. The resistance observed in the $F_{1}$ and progeny from the backcross to the resistant parent indicated that resistance to BICMV in 'White Acre-BVR' was dominant. Furthermore, a 1 resistant : 1 susceptible segregation of progeny from the backcross to the susceptible parent and a 3 resistant : 1 susceptible segregation of the $F_{2}$ progenies suggested that the resistance to BICMV in 'White AcreBVR' was conferred by a single dominant gene.

The cowpea, also known as southernpea, crowder pea, or blackeye pea, is grown throughout the world for human and animal consumption. Virus diseases are serious limiting factors in cowpea production (Collins et al., 1985; Harrison and Gudauskas, 1968; Pio-Ribeiro et al., 1978). Blackeye cowpea mosaic virus (BICMV) is the most important seedborne virus of the species in the southeastern United States (Lima et al., 1979) and occurs either singly or in mixed infections with other mosaic viruses (Pio-Ribeiro et al., 1978). A mixed infection of BICMV and cucumber mosaic virus (CMV) results in a synergistic interaction called cowpea stunt that was found to cause yield loss in 'California Blackeye No. 5' of up to $86.4 \%$ (PioRibeiro et al., 1978). Since there is no known source of resistance to CMV in commercial cowpea cultivars, the occurrence of cowpea stunt can be prevented by growing cultivars with resistance to BICMV.

Resistance to BICMV in cowpea was found to be governed by a single recessive gene in

Received for publication 12 Apr. 1990. Part of a thesis submitted by S.O. in partial fulfillment of the requirements for the MS degree. Journal paper no. 11-902527P of the Alabama Agricultural Experiment Station. We thank C.W. Kuhn for providing BICMV antisera and P.B. Strniste for his help in the conductance of the enzyme-linked immunosorbent assay. The cost of publishing this paper was defrayed in part by the payment of page charges. Under postal regulations, this paper therefore must be hereby marked advertisement solely to indicate this fact.

'Graduate Student.

${ }^{2}$ Professor
'TVU 2480' (Taiwo et al., 1981) and in 'Worthmore' (walker and Chambliss, 1981). Strniste (1987) found resistance in 'Pinkeye Purple Hull-BVR' to be controlled by a single dominant gene. This gene was not allelic to the gene for resistance to BICMV in 'Worthmore'. The objective of our study was to determine the mode of inheritance of resistance to BICMV in 'White Acre-BVR', an important processing cowpea. It originated from selections made during a study to evaluate the disease reactions of cowpea cultivars to single and mixed infections of BICMV and CMV (Kuhn et al., 1984; PioRibeiro and Kuhn, 1980). 'White Acre-BVR' came from a seed lot of 'White Acre', with nearly all plants extremely resistant to BICMV (Kuhn et al., 1984). Understanding the mode of inheritance of resistance to BICMV in this cultivar with an extremely high degree of resistance to BICMV will probably be helpful to cowpea breeders.

Seeds of 'White Acre-BVR' and 'California Blackeye No. 5' were planted in the greenhouse at Auburn, Ala., in 15-cm-diameter clay pots $\left(1600 \mathrm{~cm}^{3}\right)$ during Winter and Spring 1989 and fertilized weekly. Handpollinations were made following the method described by Blackhurst and Miller (1980), and $F_{1}, F_{2}$, and backcross populations, including reciprocals, were generated.

Seven screening tests were conducted in the greenhouse in 1989. Each test included two plants of 'White Acre-BVR', two plants of 'California Blackeye No. 5', 12 F plants, 10 plants of each backcross, $20 \mathrm{~F}_{2}$ plants, two known positive controls ('California Blackeye No. 5'), and two known negative 
Table 1. Reactions of resistant and susceptible parent cultivars and progenies of crosses and backcrosses to blackeye cowpea mosaic virus incubation.

\begin{tabular}{|c|c|c|c|c|c|c|c|c|c|c|}
\hline \multirow[b]{3}{*}{ Progeny } & \multicolumn{8}{|c|}{ No. plants } & \multirow[b]{3}{*}{$x^{2}$} & \multirow[b]{3}{*}{ Prob. } \\
\hline & \multirow[b]{2}{*}{ Total } & \multicolumn{3}{|c|}{ Reaction $^{2}$} & \multicolumn{2}{|c|}{ Observed $^{y}$} & \multicolumn{2}{|c|}{ Expected $y$} & & \\
\hline & & NS- & $\mathrm{NS}^{+}$ & $\overline{S^{+}}$ & $\mathrm{R}$ & $S$ & $\mathrm{R}$ & $\bar{S}$ & & \\
\hline WA-BVR & 14 & 14 & 0 & 0 & 14 & 0 & 14 & 0 & $\ldots$ & $\cdots$ \\
\hline $\mathrm{CBE}^{w}$ & 14 & 0 & 0 & 14 & 0 & 14 & 0 & 14 & $\cdots$ & $\cdots$ \\
\hline $\mathrm{F}_{1}$ & 84 & 84 & 0 & 0 & 84 & 0 & .84 & 0 & $\cdots$ & -- \\
\hline$F_{1} \times$ WA-BVR & 70 & 70 & 0 & 0 & 70 & 0 & 70 & 0 & -- & ... \\
\hline $\mathrm{F}_{1} \times \mathrm{CBE}$ & 70 & 38 & 2 & 30 & 38 & 32 & 35 & 35 & 0.51 & $>0.25$ \\
\hline $\mathrm{F}_{2}$ & 140 & 101 & 3 & 36 & 101 & 39 & 105 & 35 & 0.61 & $>0.25$ \\
\hline
\end{tabular}

${ }^{2} \mathrm{NS}=$ no symptoms and negative ELISA for BICMV; $\mathrm{NS}^{+}=$no symptoms and positive ELISA for $\mathrm{BICMV} ; \mathrm{S}^{+}=$symptoms and positive ELISA for BICMV.

${ }^{ } \mathrm{R}=$ resistant, $\mathrm{S}=$ susceptible.

'WA-BVR = 'White Acre-BVR'.

"CBE = 'California Blackeye No. 5'.

controls ('White Acre-BVR'). The seedlings were mechanically 'inoculated with BICMV 9 days after planting. BICMV-infected trifoliolate leaves of the highly susceptible 'Knuckle Purple Hull' with BICMV symptoms were ground in a mortar and pestle in $0.05 \mathrm{M}$ phosphate buffer $(\mathrm{pH} 7.4)$ at the rate of $1 \mathrm{~g}$ leaf tissue $/ 2 \mathrm{ml}$ buffer solution. The resulting sap was applied with cotton swabs to the upper surface of both primary leaves of each tested plant previously dusted with 600-mesh Carborundum. Inoculated leaves were rinsed with water to avoid wounded cell desiccation and to increase virus infectivity.

The gamma globulin $(\operatorname{Ig} G)$ conjugation and enzyme-linked immunosorbent assay (ELISA) test were conducted with BICMV antiserum provided by C.W. Kuhn (Dept. of Plant Pathology, Univ. of Georgia, Athens) following the methods described by Clark and Adams (1977), McLaughlin et al. (1981), and Voller et al. (1976). Each ELISA plate included one 'White Acre-BVR', one 'California Blackeye No.5', six $F_{1}$, five of each backcross, $10 \mathrm{~F}_{2}$, and two control samples. Trifoliolate leaves of the plants were collected as samples. Two plates were used to accommodate each screening test. To avoid a plate effect, the outside rows-of the wells in the plate were not used, and all samples were duplicated at random on each plate.

Symptom expression and ELISA results were used to distinguish resistant from susceptible plants. Plants showing typical symptoms of BICMV at 4 weeks after inoculation were rated $\mathrm{S}$ and the symptomless plants were rated NS. ELISA results were considered positive for BICMV when the average absorbency value of duplicate test wells was at least twice that of known negative controls. Individual plants were rated $\mathrm{S}^{+}$if they developed BICMV symptoms and gave a positive ELISA reaction; $\mathrm{NS}^{+}$if no BICMV symptoms developed but ELISA tests indicated the presence of BICMV; and NS if no symptoms developed and ELISA reactions were negative. NS plants were considered resistant, and $\mathrm{NS}^{+}$and $\mathrm{S}^{+}$plants were considered susceptible to BICMV.

There were no differences in reaction to BICMV infection among the reciprocal crosses. Therefore, the data were pooled for further analysis. Susceptible plants showed backcross to the susceptible parent supported a single dominant gene inheritance model.

From the results of this investigation, we concluded that a single dominant gene controls resistance to BICMV in 'White AcreBVR'. The same mode of inheritance was implicated in the resistance to BICMV in 'Pinkeye Purple Hull-BVR' (Strniste, 1987) and in the bean (Phaseolus vulgaris L.) cultivar Black Turtle Soup (Provvidenti et al., 1983). This simple dominant inheritance of resistance to BICMV can be exploited easily in breeding programs designed to transfer BICMV-resistance to desirable commercial cowpea cultivars and to aid in the control of cowpea stunt.

\section{Literature Cited}

symptoms that included vein-clearing, veinbanding, and malformation and blistering of the trifoliolate leaves by 2 weeks after inoculation. Delay in symptom development, as compared to studies of Pio-Ribeiro and Kuhn (1980), may have been due to slightly higher temperatures (16 to $34 \mathrm{C}$ ) during the incubation period in the present study.

Results from ELISA were highly correlated with the visual symptom ratings. ELISA readings for known positive (0.12 to 0.44 ) and negative $(0.00$ to 0.03$)$ samples indicated adequate separation of BICMV-infected and noninfected samples. All inoculated 'California Blackeye No. 5' plants showed severe virus symptoms and positive ELISA values (0.05 to 0.77). 'White Acre-BVR' plants did not express symptoms, and their ELISA values $(0.00$ to 0.02$)$ were negative for BICMV-infection. These results confirmed those of Anderson (1955) and Kuhn et al. (1984).

The $84 \mathrm{~F}_{1}$ plants and the 70 backcross plants to the BICMV-resistant parent 'White AcreBVR' did not develop symptoms and showed negative ELISA results (Table 1), indicating that resistance to BICMV in 'White AcreBVR' is dominant to susceptibility. Of the 70 plants backcrossed to the BICMV-susceptible parent 'California Blackeye No. 5', 38 were symptomless and tested negative for BICMV with ELISA. Two plants did not develop symptoms after 4 weeks, but ELISA results indicated that they were infected with BICMV (Table 1). The lack of symptom expression may have been due to an insufficient titer of the virus or to the genotype of these plants. Kuhn et al. (1981) indicated that host genotype conditioned the expression of symptoms. Within two to 4 weeks after inoculation, 30 of the 70 plants exhibited symptoms and gave positive ELISA reaction for BICMV. A $\chi^{2}$ test showed that the ratio of 38 resistant : 32 susceptible was not significantly different from the expected 1:1 ratio (Table 1).

Of the $140 \mathrm{~F}$, plants evaluated, $101 \mathrm{did}$ not express symptoms and their ELISA reactions were negative for BICMV infection. Three symptomless plants gave positive ELISA reaction for BICMV. The ratio of 101 resistant : 39 susceptible was not significantly different from the expected 3:1 ratio (Table 1). The results of $F_{2}$ and the
Anderson, C.W. 1955. Vigna and Crotalaria viruses in Florida. H. Notations concerning cowpea mosaic virus (Marmor vignae). Plant Dis. Rptr. 39:349-352.

Blackhurst, H.T. and J.C. Miller, Jr. 1980. Cowpeas, p. 327-337. In: W.R. Fehr and H.H. Hadley (eds.). Hybridization of crop plants. Amer. Soc. Agron. and Crop Sci. Soc. Amer., Madison, Wis.

Clark, M.F. and A.N. Adams. 1977. Characteristics of the microplate method of enzyme-finked immunosorbent assay (ELISA) for the detection of plant viruses. J. Genet. Virol. 34:475-483.

Collins, M.H., W. Witcher, O.W. Barnett, and W.L. Ogle. 1985. Reactions of 16 cowpea cultivars to six viruses. Plant Dis. 69:18-20.

Harrison, A.N. and R.T. Gudauskas. 1968. Effects of some viruses on growth and seed production of two cowpea cultivars. Plants Dis. 52:509-511.

Kuhn, C.W., B.B. Brantley, J.W. Demski, and G. Pio-Ribeiro. 1984. 'Pinkeye Purple HullBVR', 'White Acre-BVR', and 'Corona' cowpeas. HortScience 19:592. Genetic control of symptoms, movement and virus accumulation in cowpea plants infected with cowpea chlorotic mottle virus. Phytopathology 71:1310-1315.

Lima, J.A.A., D.E. Purcifull, and E. Hiebert. 1979. Purification, partial characterization, and serology of blackeye cowpea mosaic virus. Phytopathology 69:1252-1258.

McLaughlin, M.R., O.W. Bennett, P.M. Burrows, and R.H. Brown. 1981. Improved ELISA conditions for the detection of plant viruses. J. Virol, Methods 3:13-25.

Pio-Ribeiro, G. and C.W. Kuhn. 1980. Cowpea stunt: Heterogeneous and differential reactions of cowpea cultivars. Phytopathology 70:244249

Pio-Ribeiro, G., S.D. Wyatt, and C.W. Kuhn. 1978. Cowpea stunt: A disease caused by a syaergistic interaction of two viruses. Phytopathology 68:1260-1265.

Provvidenti, R., D. Gonsalves, and M.A. Taiwo. 1983. Inheritance of resistance to blackeye cowpea mosaic and cowpea aphid-borne mosaic viruses in Phaseolus vulgaris. J. Hered. 74:6061.

Strniste, P.B. 1987. The inheritance and assessment of a second qualitative gene for blackeye cowpea mosaic virus resistance in southernpea, Vigna unguiculata (L.) Walp. MS Thesis, Auburn Univ., Auburn, Ala.

Taiwo, M.A., R. Provvidenti, and D. Gonsalves. 1981. Inheritance of resistance to blackeye cowpea mosaic virus in Vigna unguiculata. J.
Kuhn, C.W., S.D. Wyatt, and B.B. Brantley. 1981. 
Hered. 72:433-434.

Voller, A., A. Bartlett, D.E. Bidwell, M.F. Clark, and A.N. Adams. 1976. Detection of viruses by enzyme-linked immunosorbent assay

(ELISA). J. Genet. Virol. 33:165-167.

Walker, C.A., Jr., and O.L. Chambliss. 1981.
Inheritance of resistance to blackeye cowpea mosaic virus in Vigna unguiculata (L.) Walp. J. Amer. Soc. Hort. Sci. 106:410-412. 